\title{
Some Problems on Dispersion Coefficient and Simulation for Pesticide Leaching through Soil ${ }^{*}$
}

\author{
Kazuo Nose \\ National Institute of Agricultural Sciences, Yatabe, Tsukuba, Ibaraki 305, Japan
}

(Received April 28, 1983)

\begin{abstract}
Dispersion coefficients $D$ resulting from Tsukuba soil-picric acid leaching system showed a large variance, but they had a tendency to increase with the pore-water velocity $U$, representing the regression equation $D=0.46 U-0.053, U>0.1 \mathrm{~cm} / \mathrm{min} . \quad D$ seemed to be independent of $U$ below $0.1 \mathrm{~cm} / \mathrm{min}$ and the average was $0.012 \mathrm{~cm}^{2} / \mathrm{min}$. A $3 \mathrm{~cm}$ length soil column showed two peaks before and after the simulation peak, while a $27 \mathrm{~cm}$ length soil column showed one peak before the simulation peak. This phenomenon is explicable by the wall effect. Konosu paddy soil-picric acid system resulted in $0.14 \mathrm{~cm}^{2} / \mathrm{min}$ of $D$ independent of $U$. The Freundlich's adsorption coefficients of picric acid and oxamyl were 3.84 and 0.33 in ppm unit and the indexes were 0.816 and 0.828 , respectively. Tsukuba soil-oxamyl leaching system gave $0.008 \mathrm{~cm}^{2} / \mathrm{min}$ of $D$ at a low $U 0.06 \mathrm{~cm} / \mathrm{min}$, which was the similar value as Tsukuba soilpicric acid leaching system. This suggests that the soil types affect more greatly on the dispersion coefficient than the kind of leached chemicals.
\end{abstract}

\section{INTRODUCTION}

Two leaching processes should be considered for the simulation of leaching. First one is the process in which a solution is continuously applied to the top soil and this is called the continuously loading process (C-process) here. In my previous report, ${ }^{1)}$ factors necessary for the simulation of the leaching by the C-process were discussed with the experimental results which allowed the dispersion coefficient to be extracted by Rose and Passioura's method, ${ }^{2}$ while the other factors were determined by the usual methods. After a certain amount of a soluble chemical is applied to the top soil, the chemical starts to be eluted with a continuous flow of water in the second process. This is called the previously loaded process (P-process) here. The direct extraction of the dispersion coefficient from the result by the P-process is not easy because of the mathematic complexity and the large effect of the concentration differ-

* Leaching of Pesticide and Related Chemicals in Soil (Part 4). See Ref. 1). ences by the adsorption. Davidson and Chang, ${ }^{3)}$ however, extracted it from the lefthand portion of the experimental curve. The examination of dispersion coefficients by the C-process is then important for the successful estimation of the dispersion coefficient employed on the simulations of the P-process and the field leachings.

\section{EXPERIMENT}

\section{Soil, Apparatus, and Test Chemicals}

Almost the same materials as reported in author's previous paper $^{1)}$ were used, and Kanamegawa soil, Konosu soil, oxamyl $[N$, $\mathrm{N}$-dimethyl-2-methyl-carbamoyloxyimino-2(methylthio)acetamide] and a long column with $27 \mathrm{~cm}$ diameter were also used. The properties of soils are listed in Table 1. A 99\% oxamyl standard was presented by $\mathrm{Du}-$ Pont Co.

\section{Procedure for C-leaching}

The same method as the previous paper ${ }^{1)}$ was used. 
Table 1 Properties and parameters of soils.

\begin{tabular}{|c|c|c|c|}
\hline Soil & $\begin{array}{l}\text { Tsukuba } \\
\text { upland }\end{array}$ & $\begin{array}{c}\text { Kanamegawa } \\
\text { upland. }\end{array}$ & $\begin{array}{l}\text { Konosu } \\
\text { paddy }\end{array}$ \\
\hline Origines & Volcanic ash & Alluvial & Alluvial \\
\hline Texture & SL & SCL & $\mathrm{CL}$ \\
\hline $\mathrm{CEC}(\mathrm{mEq} / 100 \mathrm{~g})$ & 22 & $25^{\text {a) }}$ & $15^{\mathrm{a})}$ \\
\hline Total $C(\%)$ & 4.8 & $1.2^{\mathrm{a})}$ & $1.8^{\mathrm{a})}$ \\
\hline Water capacity, $\theta(\mathrm{ml} / \mathrm{ml})$ & 0.611 & 0.549 & 0.625 \\
\hline Stationary liquid ratio, $\omega(\mathrm{ml} / \mathrm{ml})$ & 0.274 & 0.155 & 0.657 \\
\hline Bulk density, $\rho(\mathrm{g} / \mathrm{ml})$ & 0.498 & 0.640 & 0.750 \\
\hline \multicolumn{4}{|c|}{ Freundlich's adsorption constant between soils and picric acid } \\
\hline Coefficient (ppm) & 3.84 & 0.546 & 1.24 \\
\hline Coefficient (ppb) & 13.6 & 2.03 & 1.62 \\
\hline Index & 0.816 & 0.810 & 0.961 \\
\hline Dispersion coefficient $\left.\left(\mathrm{cm}^{2} / \mathrm{min}\right)^{\mathrm{b}}\right)$ & 0.012 & $\begin{array}{l}0.016 \\
\text { or less }\end{array}$ & 0.141 \\
\hline
\end{tabular}

a) Data from each experimental station.

b) Final dispersion coefficient from soil-picric acid.

\section{Procedure for P-leaching}

Two point two seven five milli-liters of $1320 \mathrm{ppm}$ picric acid solution was dropped on the soil column and then eluted with water. The eluate was introduced into a flow cell for the spectrophotometric determination as described previously. ${ }^{1)}$

\section{Determination of Oxamyl}

Oxamyl in the eluate was determined by the same procedure as for the picric acid as described previously. ${ }^{1)}$ Adsorption equation of oxamyl on Tsukuba soil was obtained as follows:

Twenty milli-liters each of $154 \mathrm{ppm}, 30.9$ $\mathrm{ppm}, 6.18 \mathrm{ppm}$ and $1.24 \mathrm{ppm}$ oxamyl solutions was shaken with $10 \mathrm{~g}$ of Tsukuba soil for $30 \mathrm{~min}$. The $50 \mu \mathrm{l}$ of supernatant solution after centrifugation was injected into a highpressure liquid chromatograph (Kyowa-seimitsu) equipped with a $20 \mathrm{~cm}$ length ODS column and eluted with $20 \%$ methanol at a rate of $2 \mathrm{ml} / \mathrm{min}$.

The resulting equation was

$$
\begin{gathered}
Q=0.329(\mathrm{ppm}) \text { or } 1.08(\mathrm{ppb}) C^{0.828}, \\
r^{2}=0.9982
\end{gathered}
$$

where $Q$ is the adsorbed amount ( $\mu \mathrm{g}$ or $n g / g$ ), $C$, the concentration of solution (ppm or $\mathrm{ppb}$ ) and $r^{2}$, the coefficient of determination.

\section{Simulation}

The same differential equation as described previously $^{1)}$ was used. After a short period of C-process for loading a definite amount of chemical, P-process was started for running after the concentration in the first array was replaced by nearly zero.

\section{RESULTS AND DISCUSSION}

1. Estimation of Dispersion Coefficient

\subsection{Relationship between dispersion coefficient and pore-water velocity}

As an idea of dispersion coefficient is an analogue of heat transfer coefficient, it was regarded as a constant. But the dispersion coefficient obtained from the leaching experiment is affected by various factors of turbulence such as small vibrations of soil column, heat convection, swift movement of liquid phase, etc. Hornsley and Davidson assumed that the dispersion coefficient for fluometuron was equal to that of chloride and determined it from chloride data. ${ }^{4)}$ Genuchten et al. ${ }^{5}$ ) used experimentally obtained $D$ values which increase with the pore-water velocity. Rao et $a l .{ }^{6)}$ used the $D$ value obtained from the tritiated water for 2,4-D and atrazine. Few reports, however, discussed the relationship between the dispersion coefficient, the porewater velocity and the other turbulences.

Dispersion coefficients in author's previous paper $^{1)}$ which were obtained from the Cprocess are plotted along the ordinate and the pore-water velocity along the abscissa (Fig. 1). 


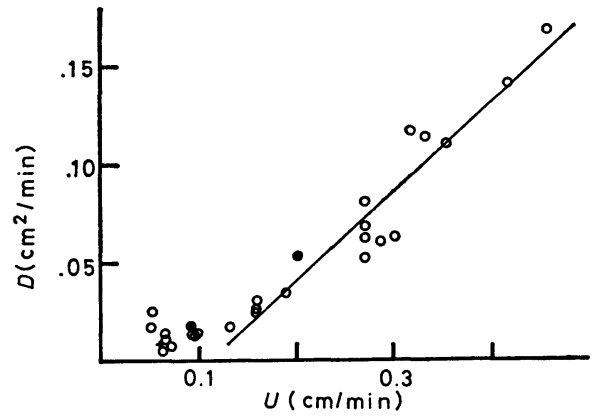

Fig. 1 Pore-water velocity $U$ and dispersion coefficient $D$.

Regression line $D=0.46 U-0.053(U>0.1)$ is obtained from Tsukuba soil-picric acid. Open circle: Tsukuba soil-picric acid, closed circle: Kanamegawa soil-picric acid, +symbol: 'Tsukuba soil-oxamyl.

The dispersion coefficient increased with the pore-water velocity when it was faster than $0.1 \mathrm{~cm} / \mathrm{min}$. The regression line was represented by an equation $D=0.46 U-0.053$. No significant relationships between $U$ and $D$ were observed when $U$ was below $0.1 \mathrm{~cm} / \mathrm{min}$, and the average of $D$ was $0.012 \mathrm{~cm}^{2} / \mathrm{min}$.

The effect of the pore-water velocity on the dispersion coefficient was obvious as shown in Fig. 1, although it was concealed within the other turbulence factors if $U$ was slower than $0.1 \mathrm{~cm} / \mathrm{min}$. The critical pore-water velocity and the corresponding dispersion coefficient are called the final velocity and the final dispersion coefficient here. The isolation of turbulence factors except for the pore-water velocity are difficult. As these turbulences probably originated from the uncontrolled laboratory conditions, the final velocity and the final dispersion coefficient may have varied. Presumably, it is true that the dispersion coefficient should converge to the self diffusion coefficient if all the turbulence factors were to be removed.

\subsection{Reproducibility of dispersion coefficient with the same column}

A column was repeatedly tested for the determination of $D$. The resulting $D$ (experimental $D$ ) was compared with $D$ on the regression line (regressional $D$ ) at the same $U$ (Table 2). Both $D$ 's were not very different from one another. That is, as the standard deviation of $D$ corrected by the regression line was $0.015 \mathrm{~cm}^{2} / \mathrm{min},{ }^{1)}$ the differences between both $D$ 's were within the error. This suggested that the large variance of $D$ was caused by the variance of column and the stable value of $D$ is expected for the field leaching when the field soil settles satisfactorily by the weathering or other means.

\subsection{Effect of column size}

The experimental $D$, obtained from the column containing $20-30 \mathrm{~g}$ of soil, was in rough agreement with the regressional $D$ even though the column length differed from $3 \mathrm{~cm}$ to $27 \mathrm{~cm}$ (Table 3). The experimental $D$, however, seemed to increase with the amount of soil when it exceeded $40 \mathrm{~g}$. The final $D$ and $U$ seemed to vary according to the amount of soil packed in the column.

\section{Leaching Curve by P-process}

The experimental curves obtained by the short column (Fig. 2) and by the long column (Figs. 3 and 4) are shown by the solid line and

Table 2 Reproducibility of dispersion coefficient with same column.

\begin{tabular}{cccc}
\hline Iteration & $U(\mathrm{~cm} / \mathrm{min})$ & Exp. $D$ & Reg. $D$ \\
\hline 1st & 0.415 & 0.141 & 0.138 \\
2nd & 0.314 & 0.079 & 0.091 \\
3rd & 0.312 & 0.095 & 0.091 \\
4th & 0.097 & 0.016 & $\left.0.012^{\mathrm{a}}\right)$ \\
1st & 0.445 & 0.169 & 0.154 \\
2nd & 0.312 & 0.084 & 0.091 \\
3rd & 0.234 & 0.039 & 0.055 \\
\hline
\end{tabular}

a) Average below $0.1 \mathrm{~cm} / \mathrm{min}$ of $U$.

Reg. $D=0.46 U-0.053$. 
Table 3 Influence of column size on dispersion coefficient.

\begin{tabular}{cccccc}
\hline \multicolumn{2}{c}{ Column } & $\begin{array}{c}\text { Amount of } \\
\text { soil } \\
(\mathrm{g})\end{array}$ & $\begin{array}{c}U \\
(\mathrm{~cm} / \mathrm{min})\end{array}$ & $\begin{array}{c}\text { Exp. } D \\
\left(\mathrm{~cm}^{2} / \mathrm{min}\right)\end{array}$ & $\begin{array}{c}\text { Reg. } D \\
\left(\mathrm{~cm}^{2} / \mathrm{min}\right)\end{array}$ \\
\hline $\begin{array}{c}\text { Diameter } \\
(\mathrm{cm})\end{array}$ & 3.3 & 30 & 0.162 & 0.033 & 0.022 \\
4.0 & 3.3 & 30 & 0.054 & 0.0063 & $0.012^{\mathrm{a})}$ \\
4.0 & 27 & 20 & 1.88 & 0.872 & 0.809 \\
1.2 & 27 & 20 & 2.35 & 1.50 & 1.03 \\
1.2 & 1.7 & 10 & 0.1 & 0.0196 & $0.012^{\mathrm{a})}$ \\
3.2 & 3.3 & 20 & 0.1 & 0.0142 & $0.012^{\mathrm{a})}$ \\
3.2 & 6.5 & 40 & 0.1 & 0.0261 & $0.012^{\mathrm{a})}$ \\
3.0 & 10.5 & 60 & 0.1 & 0.0288 & $0.012^{\mathrm{a})}$ \\
3.0 & 13.5 & 80 & 0.1 & 0.0474 & $0.012^{\mathrm{a})}$ \\
3.0 & 17.0 & 100 & 0.1 & 0.108 & $0.012^{\mathrm{a})}$ \\
\hline
\end{tabular}

a) Average below $0.1 \mathrm{~cm} / \mathrm{min}$ of $U$.

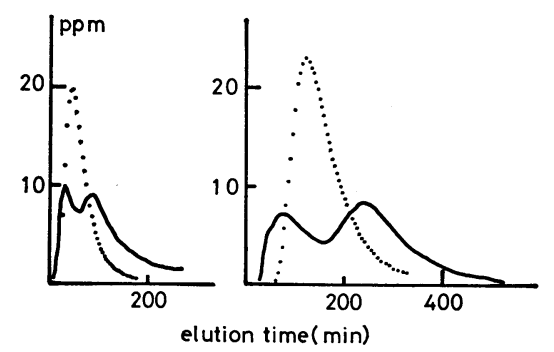

Fig. 2 Elution of picric acid through $3.3 \mathrm{~cm}$ Tsukuba soil column.

Ordinate represents elution concentration. Solid and dotted lines represent experimental and simulation curves, respectively.

Simulation condition; left figure: column length $=3.3 \mathrm{~cm}, \quad U=0.216 \mathrm{~cm} / \mathrm{min}, D=0.057 \mathrm{~cm}^{2} / \mathrm{min}$, right figure: column length $=3.3 \mathrm{~cm}, U=0.090$ $\mathrm{cm} / \mathrm{min}, D=0.012 \mathrm{~cm}^{2} / \mathrm{min}$.

the simulation curves by the broken line. In the curve by the short column, two peaks appeared before and after the simulation peak. The long column showed one peak in the faster position than the simulation peak. These may imply the wall effect, i.e., there may be two routes of leaching in which one is passed through the soil in the column and another along the wall. The latter makes the elution more quickly.

If the wall effect can be assumed to give the same effect when the column length is shortened by $20 \%$, the simulation curve is in good agreement with the experimental one although an appropriate dispersion coefficient

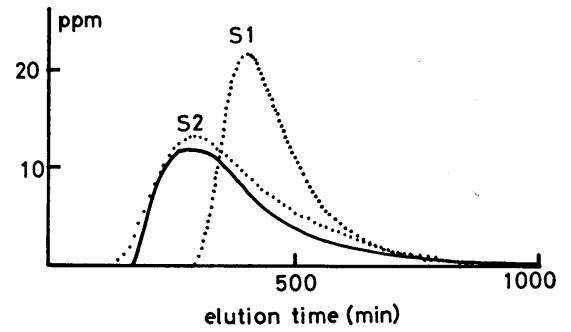

Fig. 3 Elution of picric acid through $27 \mathrm{~cm}$ Tsukuba soil column.

Symbols are the same as those of Fig. 2 .

Simulation condition; S1: column length $=27.0$ $\mathrm{cm}, \quad U=0.240 \mathrm{~cm} / \mathrm{min}, \quad D=0.066 \mathrm{~cm}^{2} / \mathrm{min}, \quad \mathrm{S} 2$ : column length $=21.6 \mathrm{~cm}, U=0.240 \mathrm{~cm} / \mathrm{min}, D=$ $0.264 \mathrm{~cm}^{2} / \mathrm{min}$.

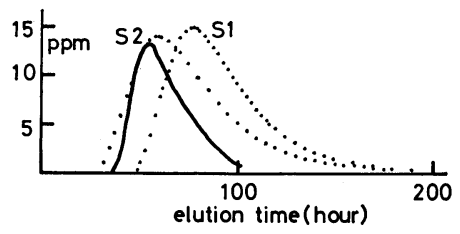

Fig. 4 Elution of picric acid through $27 \mathrm{~cm}$ Tsukuba soil column.

Symbols are the same as those of Fig. 2.

Simulation condition; S1: column length $=27.0$ $\mathrm{cm}, U=1.22 \mathrm{~cm} / \mathrm{hr}, D=0.752 \mathrm{~cm}^{2} / \mathrm{hr}$, S2: column length $=21.6 \mathrm{~cm}, U=1.22 \mathrm{~cm} / \mathrm{hr}, D=1.08 \mathrm{~cm}^{2} / \mathrm{hr}$.

should be selected (Figs. 3 and 4). The slender peak obtained from the low pore-water velocity condition may be caused by the microbial attack (Fig. 4). 


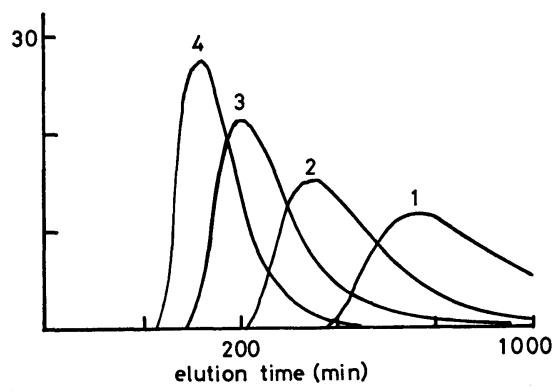

Fig. 5 Leaching shift caused by initial amount. Ordinate represent concentration ratio of eluate to initial, multiplied by $1.32 \times 10^{2}$.

Simulation condition: column length $=27 \mathrm{~cm}$, $U=0.24 \mathrm{~cm} / \mathrm{min}, D=0.066 \mathrm{~cm}^{2} / \mathrm{min}$, and initial amounts are $2.275 \mathrm{ml}$ of $1.32 \mathrm{~K} \mathrm{ppm}$, where $K$ are $10,10^{2}, 10^{3}$ and $10^{4}$ for curves $1,2,3$ and 4 , respectively.

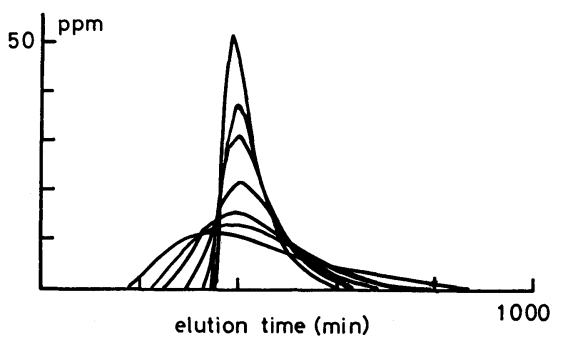

Fig. 6 Leaching shift caused by dispersion coefficient.

Simulation condition: column length $=27 \mathrm{~cm}$, $U=0.240 \mathrm{~cm} / \mathrm{min}, D=0.011,0.022,0.033,0.066$, $0.132,0.196$ and $0.33 \mathrm{~cm}^{2} / \mathrm{min}$ in the descending order of peaks.

The effect of the previously loaded amount on the peak shift is shown by the simulation (Fig. 5). The smaller the loaded amount, the later the retention time. The similar shift of the peak caused by the loaded amount was reported for 2,4-D and atrazine by Rao and Davidson. ${ }^{7)}$ Little effect of the dispersion coefficient on the peak shift is observed by the simulation (Fig. 6). These results explain the reason why one peak in the experimental curve by the short column appeared at the slower position than that of the simulation peak, because not all the loaded chemicals were leached through the soil and the pore-water velocity of the soil may be slower than the one along the wall.

\section{Effect of Soils and Chemicals}

Dispersion coefficients obtained from Konosu soil- and Kanamegawa soil-picric acid elution systems are shown in Table 4 . The final velocity and dispersion coefficient resulted from the Konosu soil-picric acid system were 0.28 $\mathrm{cm} / \mathrm{min}$ and $0.14 \mathrm{~cm}^{2} / \mathrm{min}$, respectively. The final dispersion coefficient resulted from the Kanamegawa soil-picric acid system was $0.016 \mathrm{~cm}^{2} / \mathrm{min}$ or less. Thus large differences in the final velocity and the final dispersion coefficient were observed among different soils. An example of Tsukuba soil-oxamyl system, which showed considerably small adsorption, resulted in $0.008 \mathrm{~cm}^{2} / \mathrm{min}$ of $D$ at $0.06 \mathrm{~cm} / \mathrm{min}$ of $U$. The $D$ value is approximately the same as that of picric acid (Fig. 1). It is suggested that the soils exert greater effect on the final velocity and the final dispersion coefficient than that by the leached chemicals. The effect of chemicals on the final dispersion coefficient, however, should be investigated further because only two chemicals were compared.

\section{CONCLUSION}

The dispersion coefficient is an important factor for the simulation of leaching, and the estimation is inevitable for the $\mathrm{P}$-process leaching and the field leaching because the direct determination of these is not easy. The variance of dispersion coefficients from the C-process was so large that the

Table 4 Pore-water velocity $U$ and dispersion coefficient $D$ obtained by Konosu and Kanamegawa soils and picric acid.

\begin{tabular}{ccccccc}
\hline & \multicolumn{3}{c}{ Konosu soil } & \multicolumn{2}{c}{ Kanamegawa soil } \\
\hline$U(\mathrm{~cm} / \mathrm{min})$ & 0.220 & 0.281 & 0.371 & 0.640 & 0.0915 & 0.201 \\
$D\left(\mathrm{~cm}^{2} / \mathrm{min}\right)$ & 0.133 & 0.141 & 0.314 & 0.361 & 0.0165 & 0.0506 \\
\hline
\end{tabular}


precise estimation did not seem to be easy. The obtained dispersion coefficients had the tendency to increase with the pore-water velocity when it was faster than $0.1 \mathrm{~cm} / \mathrm{min}$, and the relationship was represented by the regression equation $D=0.46 U-0.053$. The dispersion coefficient, however, seemed to be independent of pore-water velocity when it was slower than $0.1 \mathrm{~cm} / \mathrm{min}$, which is called the final velocity in the laboratory system. The average of dispersion coefficients below the final velocity, which is called the final dispersion coefficient of the laboratory, was $0.012 \mathrm{~cm}^{2} / \mathrm{min}$. The wall effect results in two peaks before and after the simulation peak by the short column experiment. The long column experiment shows one peak at the position faster than the simulation peak. Soil types presumably have greater effect on the final velocity and the final dispersion coefficient than that bv the leached chemicals.

\section{REFERENCES}

1) K. Nose: J. Pesticide Sci. 8, 1 (1983)

2) D. A. Rose \& J. B. Passioura: Soil Sci. 111, 252 (1971)

3) J. M. Davidson \& R. K. Chang: Soil Sci. Soc. Am. Proc. 36, 257 (1972)

4) A. G. Hornsby \& J. M. Davidson: Soil Sci. Soc. Am. Proc. 37, 823 (1973)

5) M. Th. van Genuchten, J. M. Davidson \& P. J. Wierenga: Soil Sci. Soc. Am. Proc. 38, 29 (1974)
6) P. S. C. Rao, J. M. Davidson, R. E. Jessup \& H. M. Selim: Soil Sci. Soc. Am. J. 43, 22 (1979)

7) P. S. C. Rao \& J. M. Davidson: Water Res. 13, 375 (1979)

$$
\text { 要約 }
$$

農薬の土㙥溶脱に関する分散係数とシミュレー ションの問題点*

能勢和夫

筑波土塨-ピクリン酸系が示す分散係数 $D$ の変動は大 きいが, 空隙水移動速度 $U>0.1 \mathrm{~cm} / \mathrm{min}$ では $D$ が $U$ とともに増大寸る傾向が認められ，その回帰式は $D=$ $0.46 U-0.053$ となった。 $U<0.1 \mathrm{~cm} / \mathrm{min}$ での $D$ の平 均は $0.012 \mathrm{~cm}^{2} / \mathrm{min}$ で, $U$ の影響は認められない. 直 径 $3.2 \mathrm{~cm}$, 長さ $3.3 \mathrm{~cm}$ 土壤カラムによる溶脱実験は計 算ピークの前後に一つずつ二つのピークを示し，直径 $3.0 \mathrm{~cm}$, 長さ $27 \mathrm{~cm}$ カラムでは計算ピークの前に一つ のピークを示した．これらは壁効果によって説明でき る. 鴻巣水田土塨一ピクリン酸系で $U$ の影響が認められ ないときは $D=0.14 \mathrm{~cm}^{2} / \mathrm{hr}$ であった. 筑波土塞へのフ ロインドリッヒ吸着係数と指数はピクリン酸で 3.84 と 0.816 , オキサミルで 0.33 と 0.828 ( $\mathrm{ppm}$ 単位) であっ た。オキサミルでは $U=0.06 \mathrm{~cm} / \mathrm{min}$ のとき $D=0.008$ $\mathrm{cm}^{2} / \mathrm{min}$ で,ピクリン酸とほぼ同一であった。これらは, 分散倸数が分散する物質自身の違いよりも土塤の違いに よって大きく影響されることを示唆している。

* 農薬等の溶脱（第 4 報） 